УДК 376.011.3-051-056.45(071)

DOI:

Богдана Турко, стариий лаборант кафедри початкової та дошкільної освіти, аспірант другого року навчання Львівського національного університету імені Івана Франка

\title{
ПРАКТИЧНА ПІДГОТОВКА МАЙБУТНІХ АСИСТЕНТІВ ДО РОБОТИ З ОБДАРОВАНИМИ ДІТЬМИ У КАНАДІ
}

Освітні реформи, які керуюсь системою освіти загалом, призвели до залучення дітей з особливими потребами та дітей, які наділені обдарованістю. Стаття присвячена актуальній проблемі підготовки спецілістів для роботи з обдарованими дітьми. Розкрито професійну підготовку асистента вчителя у канадських закладах освіти. Проаналізовано, навчальні курси та програми п'яти провінцій: Альберти, Онтаріо, Британської Колумбії, Манітоби та Саскачеван, де на освітніх факультетах проводиться підготовка парапрофесіонала. Ми визначили особливості підготовки у канадських закладах освіти: коледжі, політехніці, університеті та інституті. Зазначили, які функиії та обов'язки у співпрачі з вчителем виконує асистент у прочесі навчання обдарованих дітей.

Ключові терміни: інклюзивне навчання; навчальний процес; обдарованість; талановитість; обдаровані діти; асистент вчителя.

Табл. 1. Літ. 11.

Bohdana Turko, Senior Laboratory Assistant of the Elementary and Preschool Education Department, Postgraduate Student of the second year of study Ivan Franko National University of Lviv

\section{PRACTICAL TRAINING OF FUTURE TEACHER ASSISTANTS TO WORK WITH GIFTED CHILDREN IN CANADA}

Educational reforms that carry out the education system as a whole have led to the involvement of children with special needs and children who are endowed with giftedness. The article is devoted to the actual problem of training special specialists to work with gifted children. The professional training of a Teacher Assistant in Canadian educational institutions is revealed. It analyzes the training courses and programs in five provinces: Alberta, Ontario, British Columbia, Manitoba, and Saskatchewan, where paraprofessional training is being conducted at educational faculties. We identified the features of the preparation in four Canadian colleges, polytechnics, university and institute. They mentioned what functions and responsibilities, in cooperation with the teacher, are performed by an assistant in the process of teaching gifted children.

In the process of research, we come to the conclusion that in Canada, gifted children are categorized as children with special needs. For children who are gifted and studying in one class with ordinary children, an individual plan of education is drawn up. Therefore, teachers engage in the training of all children, the teacher's assistant helps to realize the individual plan of gifted children. We analyzed such educational institutions as: the University of Lethbridge, the University of Winnipeg, Keyno College, Spotta Show College, Saskatchewan Polytechnic, Red River College, and Oshki-Pimache-O-Win Education Institute. Educational institutions offer twoyear or one-year courses and graduate students receive a certificate or diploma. We have identified which curriculum provides a thorough training of assistant teachers to work with gifted children. The Canadian system of education is guided by the fact that each person is gifted, and support for giftedness requires the creation of a coherent, selfdirected system that would involve the identification of talented children. assistant.

Keywords: inclusive education; learning process; information processing; a talent; gifted children; a teacher

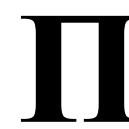

остановка проблеми. Сьогодні все більшого поширення набуває впровадження інклюзивного навчання у закладах освіти. Однією $з$ суттєвих ознак інклюзивної школи є згуртована спільнота дітей, прийняття відмінностей i реагування на індивідуальні потреби кожного. І саме це відчуття спільноти не порушується у випадку навчання у класі обдарованої дитини або дитини 3 особливими освітніми потребами. Результативне навчання таких дітей забезпечують працівники освіти.

Сучасний стан організації професійної підготовки педагогів полягає у грунтовній теоретичній та практичній готовності до співпраці 3 особливими дітьми, зокрема 3 обдарованими учнями.

Аналіз основних досліджень та публікацій. Аналіз педагогічної літератури свідчить, що дослідженню даної теми надається 


\section{ПРАКТИЧНА ПІДГОТОВКА МАЙБУТНІХ АСИСТЕНТІВ ДО РОБОТИ ЗОБДАРОВАНИМИ ДІТЬМИ У КАНАДІ}

належна увага, зокрема таким її аспектам як визначення сутності та структури обдарованості дітей (Дж. Гілфорд, К. Перлет, Дж. Рензуллі, К.А. Хеллер); підготовки спеціалістів до роботи з обдарованими дітьми (Дж. Л. Джолі, М.М. Спірман, І.Й. Любовецька, I.I. Джус, Л.О. Мокридіна, Г.В. Тарасова, М.П. Федоров, А.А. Яковина) та інші.

На міжнародному рівні найпоширенішим визначенням обдарованості та таланту $є$ твердження Франсуа Ганьє (F. Gagne), професора університету Нового Південного Уельсу. Науковець визначає обдарованих дітей, як тих, хто має високий рівень вродженої здатності, в будьякій області навчальних здібностей. Обдарованість не $є$ автоматичною гарантією успіху. Певний послідовний ряд змінних впливає на розвиток талантів, наприклад заохочення батьків, сімейні відносини, школа в якій навчається обдарована дитина, де розвиваються або не розвиваються ii таланти[9].

Мета статті - розкрити особливості підготовки асистентів вчителів до роботи 3 обдарованими дітьми.

Аналізуючи зарубіжні джерела, варто зазначити, що обдарованих дітей відносять до категорії дітей з особливими потребами, тому для забезпечення ефективного навчання залучають асистентів вчителів. Визначаємо, що термін “обдарованість” відносять до дітей, які набрали високі оцінки на тесті інтелекту вище середнього за здатністю, можуть думати і виконувати завдання творчо, демонструють надзвичайну потенційність або надзвичайну продуктивність в одному або декількох навчальних предметах або галузях науки.

Науковець Роджерс Вільям (Vialle W. Rogers) стверджує, що для дітей які є обдаровані та навчаються в одному класі із звичайними дітьми, складається індивідуальний план навчання. Педагоги обдарованих часто описують про велике терпіння дітей, які виконавши певне завдання швидше постійно повинні чекати, коли інші зроблять те ж саме завдання. Таких дітей називають “Діти Індиго” або “Діти Нового Покоління”. Особливі діти не повинні змиритися 3 жорсткістю, нудними навчальними програмами, відсутністю творчості, надмірною регламентацією, надмірною стандартизацією та обмеженими уявленнями про викладання та навчання. Удосконалення в цих сферах в контексті послідовної структурної реформи призведе не тільки до більшого визнання та навчання для обдарованих дітей, але й для всіх учнів [11].

Класна модель одного вчителя, який намагається задовольнити потреби цілого класу дітей, змінюється структурами, в яких особливі учні працюють разом з асистентом вчителя, який допомагає їм виконувати навчальну програму. Таке навчання цілком якісно забезпечує навчання усім учням без винятку, обдаровані діти включені в клас, не конкурують з іншими, а навчаються на рівні разом з іншими [10].

Враховуючи особливості поведінки обдарованих школярів, від педагогічних працівників вимагається наявність певних психофізичних якостей. Найголовнішими серед них $є$ міцне здоров'я, особлива витривалість нервово-психічної системи, уміння точно й коректно виражати свої почуття через жести, міміку. Важливою якістю педагога та асистента $\epsilon$ вміння залучати до процесу розвитку обдарованості дитини їхніх батьків, координувати свої дії з ними, надавати допомогу в усвідомленні дитячих прагнень і потреб. Участь сім'ї $\epsilon$ важливим елементом розвитку обдарованих дітей. У завдання асистента входить здійснення пошуку ефективних шляхів спільної роботи сім'і та школи. Педагоги інколи відчувають певні проблеми у процесі спілкування з батьками обдарованих учнів, які часто самі $\epsilon$ талановитими й неординарними $[1,14]$. Вирішенням даного питання потребує введення відповідної дисципліни, яку б варто було проходити майбутнім асистентам для кращої комунікації з батьками.

Асистенти роблять неоціненний внесок у підтримку та виховання дітей нового покоління, враховуючи виклики та особливості сучасної освіти. Вважаємо за доцільне, перелічити обов'язки які виконує асистент. Під час роботи з більш обдарованими учнями асистент може через діалог і взаємодію:

- забезпечити велику підтримку таким учням;

- ставити додаткові запитання, щоб розширити завдання і ввести навички мислення вищого порядку;

- заохочувати учнів продовжувати роботу або самостійно працювати;

- заохочувати прийняття ризиків та альтернативні підходи до виконання завдань;

- забезпечити мовний діалог між учнями (для поглибленого обговорення та вирішення завдання);

- запровадити диференційовані підходи до навчання та виконання завдань; - заохочувати учнів рухатися далі, коли завдання буде завершене, щоб набувати нові навички мислення та діяльності;

- заохочувати учня працювати швидше, глибше або наполегливіше, коли робота стає важкою; 


\section{ПРАКТИЧНА ПІГОТОВКА МАЙБУТНІХ АСИСТЕНТІВ ДО РОБОТИ ЗОБДАРОВАНИМИ ДІТЬМИ У КАНАДІ}

- запропонувати використовувати інші види ресурсів, матеріалів або обладнання;

- відповідати на запитання та надавати підтримку учням, похвалити за виконання завдання;

- підтримувати учня, коли вони працюють у сфері нижчого рівня досягнень, або де вони мають меншу довіру, якщо існує ризик невдачі;

- спостерігати за взаємодією учнів, що працюють в групі, записувати спостереження та подавати інформацію вчителю.

Всі перелічені вище особливості діяльності та обов'язки, які виконуватиме асистент вчителя у професійній діяльності, канадські студенти здобувають у процесі навчання у закладах освіти. У Канаді ця підготовка здійснюється не тільки для студентів, а й для батьків. Щоб здобути сертифіковану професію асистента вчителя студентам необхідно провчитись лише 1 рік, щоб здобути диплом - 2 роки. 3 метою грунтовного аналізу професійної підготовки асистента вчителя до роботи з дітьми індиго, нами було визначено у яких навчальних закладах, відбувається підготовка асистентів вчителів. У процесі дослідження вивчено документи закладів освіти п'яти провінцій Канади, зокрема провінцій Альберта, Онтаріо, Британська Колумбія, Манітоба та Саскачеван, де на освітніх факультетах проводиться курс підготовки парапрофесіонала.

Професійна підготовка асистента вчителя полягає у вивченні теоретичних та практичних навичок роботи 3 різними дітьми, зокрема 3 обдарованими учнями. Зазначмо, сім освітніх закладів різних провінцій Канади, які пропонують своїм студентам більш детально ознайомитись та вчитись працювати 3 цією категорією дітей. Наведемо у таблиці 1. провінції, назви навчальних закладів та назви дисциплін, які розкривають суть роботи з обдарованими дітьми.

Дослідження показало, що у провінції Альберта $є$ більше навчальних закладів, які готові навчати студентів допомагати у навчанні обдарованих учнів.

Таблиця 1.

Провінції, назви навчальних закладів та назви дисциплін, які розкривають суть роботи 3 обдарованими дітьми

\begin{tabular}{|c|c|c|c|}
\hline № & Провінція & $\begin{array}{c}\text { Назва закладу } \\
\text { освіти }\end{array}$ & Назва навчального курсу \\
\hline \multirow[t]{3}{*}{1.} & \multirow[t]{3}{*}{ Альберта } & $\begin{array}{c}\text { Летбриджський } \\
\text { коледж. }\end{array}$ & $\begin{array}{l}\text { - Тематичні дослідження проблемної поведінки } \\
\text { - Позитивна підтримка поведінки дітей } \\
\text { - Включення дітей з особливими потребами }\end{array}$ \\
\hline & & $\begin{array}{c}\text { Університет } \\
\text { Вінніпега. }\end{array}$ & Обдаровані діти \\
\hline & & Коледж Кейано. & $\begin{array}{l}\text { - Розвиток дитини } \\
\text { - Керівництво поведінкою дітей } \\
\text { - Особистий розвиток та взаємодія } \\
\text { - Робота з дітьми з особливими потребами } \\
\text { - Винятковість } \\
\text { - Поведінкові розлади }\end{array}$ \\
\hline 2. & $\begin{array}{l}\text { Британська } \\
\text { Колумбія }\end{array}$ & $\begin{array}{l}\text { Спотта } \\
\text { Шоу коледж. }\end{array}$ & $\begin{array}{l}\text { - Зростання та розвиток підлітків } \\
\text { - Стратегії для успіху студентів (Comp / Inc) } \\
\text { - Індивідуальне планування навчального процесу для } \\
\text { обдарованих дітей учнів з особливими потребами } \\
\text { - Підтримка учнів з особливими потребами. }\end{array}$ \\
\hline 3. & Саскачеван & $\begin{array}{c}\text { Саскачеванська } \\
\text { політехніка. }\end{array}$ & Дослідження особливостей розвитку дітей \\
\hline 4. & Манітоба & Коледж Ред-Рівер & $\begin{array}{l}\text { - Підтримка учнів з різними потребами } \\
\text { - Сприяння позитивній поведінці } \\
\text { - Корекція поведінки } \\
\text { - Підтримка навчального середовища } \\
\text { - Спостереження за дітьми та ведення документація } \\
\text { - Професіоналізм } \\
\text { - Технології навчання } \\
\text { - Обдаровані учні }\end{array}$ \\
\hline 5. & Онтаріо & $\begin{array}{l}\text { Інститут освіти } \\
\text { імені Oshki- } \\
\text { Pimache-O-Win. }\end{array}$ & Робота $з$ дітьми з особливими потребами \\
\hline
\end{tabular}




\section{ПРАКТИЧНА ПІДГОТОВКА МАЙБУТНІХ АСИСТЕНТІВ ДО РОБОТИ ЗОБДАРОВАНИМИ ДІТЬМИ У КАНАДІ}

У навчальному плані Летбриджського коледжу та Коледжі Кейано, передбачено такі предмети які пов'язані з навчанням та корекцією поведінки звичайних, обдарованих учнів та дітей 3 особливими потребами: “Тематичні дослідження проблемної поведінки”, “Позитивна підтримка поведінки дітей”, “Керівництво поведінкою дітей” та “Поведінкові розлади”. Відповідно до їх концепції асистенти мають сприймати клас як динамічне навчальне середовище, ставши повноцінним членом команди, ознайомлюються 3 підходами до творчого використання можливостей керування і підтримки відповідної поведінки учнів [3]. Розглядають різноманітні стратегії розв'язання можливих проблем у класі. Ознайомившись із загальними положеннями про розвиток дитини та принципи роботи 3 такими дітьми, вони вивчають курс "Включення дітей 3 особливими потребами” у Летбриджського коледжу та "Робота 3 дітьми 3 особливими потребами" в Коледжі Кейано. Під час вивчення цих курсів всебічно аналізуються i обговорюються стратегії навчання дітей 3 особливими потребами, в тому числі здібних дітей [5].

Відповідно до результатів дослідження, проаналізуємо вивчення навчальних дисциплін “Дослідження особливостей розвитку дітей” та “Обдаровані діти”. У Саскачеванській політехніці пропонується вивчати першу дисципліну у 3 кредитні одиниці, 45 годин, використовуючи при цьому методи навчання: лекція, теорія-практика, навчання Онлайн та попереднє навчання. Студентам буде надано основи про різні винятковості дітей. На лекційних заняттях студенти будуть обговорювати питання, тенденції в цій сфері та проблеми, пов'язані з визначенням та ідентифікацією осіб 3 винятковими особливостями, вивчатимуть конкретні сфери: мовні та мовленнєві відмінності, труднощі в навчанні, інтелектуальні обмеження або обдарованість дітей. У практичній діяльності акцент буде зроблений на наслідки розвитку дітей та стратегії навчання, що застосовуються до учнів 3 обмеженими можливостями та обдарованих дітей [6].

Університет Вінніпега пропонує вивчення другої дисципліни, а саме “Обдаровані діти”, на яку також виділено 3 кредити і час 45 аудиторних годин. Ця дисципліна розкриває студентам знання різних видів та навичок обдарованості дітей, які допомагають у розробці відповідних стратегій програмування для дітей з особливими потребами та здібностями. Студенти вивчатимуть відповідні методи та прийоми навчання i як їх використовувати, працюючи індивідуально 3 дітьми та в інтегрованих умовах. Цей предмет надасть поглиблене вивчення особливостей, що зустрічається у дітей в сучасних школах, включаючи обдарованих, емоційні та активноповедінкові діти. Будуть наводитися спеціальні стратегії для вмілого складання індивідуальних програм [8].

Отже, у визначених провінціях студенти під час навчання вивчають особливості та обдарованість дітей. Заклади освіти, які ми порівнюємо виділили однакову кількість кредитів та час аудиторних годин але бачимо і певні особливості, які притаманні кожному з окремих предметів. У підсумку майбутні асистенти засвоять теоретичну інформацію про винятковість дітей та як практично співпрацювати 3 ними, готувати програми навчання відповідно до індивідуальних особливостей кожного учня.

Привернемо увагу до підготовки асистента вчителя у Коледжі Спотта-Шоу. Особливість цього закладу полягає в тому, що загальна тривалість даної програми складає 900 годин, це в середньому 43 тижні, з яких 180 годин займає практика. По закінченню навчання студенти здобувають диплом асистента. Ефективність даної програми велика, оскільки дає можливість закріпити практичні навички у поєднанні з добрим теоретичним підгрунтям. Студенти вивчають дисципліни, про зростання та розвиток дітей, в тому числі дітей з особливими потребами, індивідуальне планування освіти для особливих дітей, підтримка студентів 3 винятковими явищами [7].

Особливість програми підготовки асистент у Інституті освіти імені Oshki-Pimache-O-Win в тому, що це дипломна програма для асистентів для класів де навчаються діти корінного населення, підготує майбутніх асистентів до роботи в школах аборигенів у північних громадах Канади. Аналізуючи дану програму визначаємо, що про обдарованих дітей студентам розповідають під час вивчення курсів: “Робота 3 дітьми корінного населення з особливими потребами” та "Розвиток дітей”. Завершивши програму для асистентів, студенти мать право працювати під професійним керівництвом вчителя та директора школи, як помічник у класі з дітьми початкової школи аборигенів $[2,1]$.

Висновок. Отже, у процесі підготовки парапрофесіонлів канададська система освіти керується тим що, кожна особистість є обдарованою, а підтримка обдарованості потребує створення цілісної, самокерованої системи, яка передбачала б виявлення 


\section{ПРАКТИЧНА ПЦДГОТОВКА МАЙБУТНІХ АСИСТЕНТІВ ДО РОБОТИ З ОБДАРОВАНИМИ ДІТЬМИ У КАНАДІ}

талановитих дітей та молоді, розвиток іiі здібностей, стимулювання творчої роботи студентів та вчителів. Творчі педагоги мають допомагати учням реалізувати власний потенціал i в процесі цього самі навчаються виявляти i розвивати обдаровання учнів. В умовах реформування освіти розвиток здібностей і обдаровань дитини $є$ важливим завданням психолого-педагогічної науки і практики. Саме тому і професійна підготовка асистента до роботи 3 обдарованими дітьми має особливе значення.

\section{ЛІТЕРАТУРА}

1. Джус I. І. Особливості підготовки вчителів до роботи з обдарованими учнями. Освіта та розвиток обдарованої особистості. 2014. № 3. С. 14 18.

2. Інститут освіти імені Oshki-Pimache-O-Win. URL: http://www.oshki.ca/aboriginal-classroomassistant

3. Коледж Кейано. URL: http://www.keyano.ca/ Academics/ Programs/Educational Assistant Certificate

4. Коледж Ред-Рівер. URL: http://rdc.ab.ca/ programs/academic-calendar/educational-assistantcertificate

5. Летбриджський коледж. URL: https:// lethbridgecollege.ca/programs/educationala s s istant? fbc lid=I w A R 316 I U

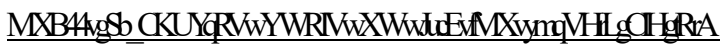

6. Саскачеванська політехніка. URL: https:// saskpolytech.ca/ programs-and-courses/programs/ Educational-Assistant.aspx

7. Спротта Шоу коледж. URL: https:// sprottshaw.com/health/ community-support-specialeducation-assistant/?fbclid=IwAR26Z10Ci2OoVf WiAGq5V1L5UnVcxGI uzrZgNOCvyq3gqFh351TUIpQIPc

8. Університет Вінніпега, URL: http:// www.portagecollege.ca /Programs/ HumanServices/Educational-Assistant-Diploma

9. Gagne F. Understanding the Complex Choreography of Talent Development through DMGT-Based Analysis. In International Handbook of Giftedness and Talent, ed. K. A. Heller, F. J. Monks, R. J. Sternberg, and R. F. Subotnik.-Oxford, UK. 2000. pp.2-3.

10. Sapon-Shevin M. Why gifted students belong to inclusive schools. URL: http://www.ascd.org/ publications/educational-leadership/dec94/vol52/ num04/Why-Gifted-Students-Belong-in-InclusiveSchools.aspx
11. Vialle W. Rogers, Educating the Gifted Learner David Barlow Publishing. KB. 2010.

\section{REFERENCES}

1. Dzhus, I. I. (2014). Osoblyvosti pidhotovky vchyteliv do roboty z obdarovanymy uchniamy [Features of training teachers to work with gifted students]. Journal of Education and development of gifted personality. No. 3. pp. 14-18. [in Ukrainian].

2. Instytut osvity imeni Oshki-Pimache-O-Win. [Oshki-Pimache-O-Win Education Institute]. Available at: http://www.oshki.ca/aboriginalclassroom-assistant. [in English].

3. Koledzh Keiano. [Keiano College]. Available at: http://www.keyano.ca/Academics/ Programs/ EducationalAssistantCertificate. [in English].

4. Koledzh Red-River. [Red River College]. Available at: http://rdc.ab.ca/programs/academic calendar/educational-assistant-certificate [in English].

5. Letbrydzhskyi koledzh. [Lethbridge College.]. Available at: https://lethbridgecollege.ca/programs/ educational-assistant? fbclid=IwAR316IU MXB44vgSb_CKUYqRVwY WRIVwXWwJuc EvfMXvymqVHrLgCIHgtRrA [in English].

6. Saskachevanska politekhnika [Saskatchewan Polytechnic]. Available at: https://saskpolytech.ca/ programs-and-courses/programs/EducationalAssistant.aspx [in English].

7. Sprotta Shou koledzh. [Sprotta Show College]. Available at: https://sprottshaw.com/health/ community-support-special-education-assistant/ ?fbclid=IwAR26Z10Ci2OoVf [in English].

8. Universytet Vinnipeha. [University of Winnipeg]. Available at: http://www.portagecollege.ca /Programs/ Human-Services/Educational-AssistantDiploma [in English].

9. Gagne, F. (2000). Understanding the Complex Choreography of Talent Development through DMGT-Based Analysis. In International Handbook of Giftedness and Talent, ed. K. A. Heller, F. J. Monks, R. J. Sternberg, and R. F. Subotnik. Oxford, UK. pp.2-3. [in English].

10. Sapon-Shevin, M. Why gifted students belong to inclusive- schools. Available at: http:// www.ascd.org/publications/educational-leadership/ dec94/vol52/num04/Why-Gifted-Students-Belong-inInclusive-Schools.aspx [in English].

11. Vialle W. Rogers, (2010). Educating the Gifted Learner David Barlow Publishing. KB. [in English].

Стаття надійшла до редакції 15.10.2019

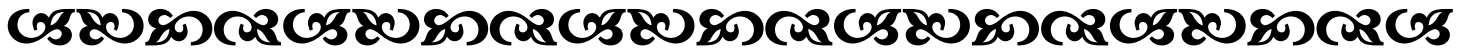

